Journal of Social Sciences 8 (3): 472-478, 2012

ISSN 1549-3652

(C) 2012 Science Publications

\title{
Employability Skill Acquisition among Malaysian Community College Students
}

\author{
Omar, M.K., A.R. Bakar and A. Mat Rashid \\ Department of Science and Technical Education, \\ Faculty of Educational Studies, Universiti Putra Malaysia, 43400 Serdang, Selangor Malaysia
}

\begin{abstract}
The objective of this study was to assess the acquisition of employability skills among Malaysian community college students. The sample size of the present study 325 students selected randomly. Employability skills were measured using an instrument developed by the Secretary's Commission on Achieving Necessary Skills (SCANS). The overall mean of employability skills among community college students was 3.63 (S.D. $=0.47)$. Thus, we consider the employability skills of community college students to be moderately high. Of all measures of employability skills, students scored the highest on personal qualities (Mean=3.86, S.D. $=0.59)$. The lowest score was identified in the area of resource skills $(M=3.52$ : S.D. $=0.55)$. Three aspects of employability measures were above the mean: basic skills $(\mathrm{M}=3.66, \mathrm{~S}$. D. $=0.59)$, interpersonal skills $(\mathrm{M}=3.72, \mathrm{SD} .=0.71)$ and personal qualities $(\mathrm{M}=3.86, \mathrm{SD} .=0.59)$. The three aspects of employability that were below the mean were thinking skills $(\mathrm{M}=3.61, \mathrm{SD} .=0.62)$, resource skills $(\mathrm{M}=3.52, \mathrm{SD} .=0.55)$ and informational skills $(\mathrm{M}$ $=3.55, \mathrm{SD} .=0.59)$. We also tested whether employability skills among students differed as a function of gender and work experience. The result of an independent t-test showed that there was no significant difference in employability skills by gender or work experience. We presented some recommendations for improve the employability skills acquisition among community college students.
\end{abstract}

Key words: Community college students, Malaysian vocational and technical education, emplyability skills

\section{INTRODUCTION}

Malaysia is aiming to become a fully developed country by the year 2020. Malaysia also aims to become a high income status country by 2020; the Gross National Income (GNI) per capita is estimated to increase from US\$5,038 in 2005 to between US\$15,000 and US $\$ 20,000$ by 2020 (GM, 2010). To support these aims, Malaysia requires a large percentage of high-skilled workers. However, between 2002 and 2007, the use of low-skilled labor increased across many industries (NEAC, 2010). As of 2007, Malaysia's labor force remains low-skilled (75\%) compared to other countries, such as Singapore (51\%), Taiwan $(67 \%)$ and Korea (65\%). Malaysia must produce more high-skilled workers if it hopes to compete with other players, at least in Asian regions. More than 50\% of Malaysian university graduates are in the arts and humanities rather than technical and science fields. By 2020, Malaysia needs 1.3 million skilled workers in at least 21 industrial groups. Efforts have been made by the Malaysian government to increase the number of skilled workers through the establishment of polytechnics, community colleges and other technical training centers. In fact, the provision of TVET in Malaysia is spread over several different ministries, agencies and state governments.

Employment is a major concern of many youths throughout the world. According to the ILO (2010), youths account for almost one-half of the world's unemployed population and the youth unemployment rate increased from $11.9 \%$ in 2007 to $13 \%$ in 2009. However, this rate is predicted to fall to $12.7 \%$ in 2011. Unemployment among youths is often the result of economic development, which causes a reduction in the number of jobs created and a restructuring of firms. Employability skills or generic skills are secondary to economic development. When jobs are abundant and potential employees are scarce, there is no unemployment problem among graduates. When the number of tertiary education graduates increases significantly, the unemployment rate among youths increases in many countries. Malaysia is no exception to this phenomenon. Although the number of graduates has increased, Robinson (2000) indicates that employers find it difficult to recruit potential workers who have employability or job readiness skills that

Corresponding Author: Bakar, A.R., Department of Science and Technical Education, Faculty of Educational Studies, Universiti Putra Malaysia, 43400 Serdang, Selangor Malaysia 


\section{J. Social Sci., 8 (3): 472-478, 2012}

enable them to fit and remain in the organization. Both technical skills and people skills (and soft skills) play important roles in employment. Technical skills are the skills needed to perform specific tasks, whereas soft skills, or people skills, are the skills needed to become employed, to remain in employment and to progress in a chosen career. A person with technical skills may not be employed because he or she lacks employability or people skills. Likewise, a person with only soft skills or people skills may find it difficult to obtain a job because he or she does not know how to perform the job correctly. Thus, potential employees need both types of skills to compete for, obtain and maintain employment.

In general, employability skills are understood as transferable skills that can be used in any organization. These skills are not job specific. They may include leadership, teamwork, negotiation, communication, thinking and a host of other skills. As explained by the CBC (2000), employability skills may be broadly defined as the basic academic, personal and teamwork skills that employers expect from their workers, which are expected to be developed by the educational system. According to Munro (2007), employability skills involve the ability to contribute to work efficiency in an organization combined with good oral and written communication skills and critical thinking, which form the foundation of both academic and workplace success. Bennett (2006) argued that employability skills include not only the attributes that are desired from prospective employees but also the basic requirements an individual needs to be considered for employment. Employability skills cannot be defined as only soft skills or people skills; they must include soft skills as well as job-specific skills. These skills are required to perform a task efficiently and to contribute to the growth of an organization.

Employability skills must be emphasized by training institutions because these skills can accelerate employment among youths and school leavers. Without these skills, youths can be considered handicapped in the race for employment. Kwok (2004) investigated the different effects of various skill requirements with the assumption that employability skills were separate from the actual work contexts in which they are learned and developed. Kwok found that the competitiveness of individuals in the labor market depends not only on their vocational competence but also on whether these individuals have employability competences that they can continue to expand. Employability competence must be developed to the extent that an individual can find a suitable job and can acclimatize to social, technological and organizational changes (Burgaz, 2008).

Students should acquire employability skills while they are at a training institution or in school. The skills can be learned through classroom instruction, in the field or outside the classroom. These skills are abstract in nature and a long time is required to train students to fully acquire employability skills. According to Knight and Yorke (2003), employability skills, or 'soft skills', include the achievement, understanding and personal attributes that make an individual willing to work, develop a career and be successful in their employment choices. Based on the factors that contribute to employment, employability skills should be redefined to include both soft skills and technical skills. It may be difficult to become employed with only soft skills; likewise, employers may hesitate to employ individuals who know how to perform a task but may not be able to contribute to the development of the organization.

Community Colleges in Malaysia: The community college system was first implemented in Malaysia in 2001. The main purpose of community colleges is to provide training for the skills needed for employment and further opportunities for post-secondary education prior to entrance into the labor market or the pursuit of higher education. From a humble beginning of 10 colleges in 2001, the community college system has grown to 72 colleges by 2011, with an enrollment of 18,200 students. As of 2010, the output of the colleges was 7,460 graduates. Almost all students are trained at the certificate level, with only 386 students trained at the diploma level. The majority of courses offered are short courses, with durations of 3 months to 6 months. The nature of community colleges perfectly suits the purpose of upgrading skills to enhance job performance. This purpose is reflected in the objectives of the establishment of the community college system: providing education and skill training to all levels of society, organizing and providing lifelong learning for the community (e-community) and organizing and enhancing training (up-skilling), skills (re-skilling) and attachment (for the needs of the local workforce. Community college training is a skill-training program based on the actual work process and conducted on a full-time and part-time basis. The training is open to everyone without limitations on age, gender or race. The government intends to establish one community college for every parliamentary seat in Malaysia.

The community college system in Malaysia is based on a different concept than the community college system in the United States, in which students have two options for enrollment: A transfer program or employment. Both options require students to enroll for two years to be awarded the certificate. In Malaysian community colleges, students may enroll in short courses as well as in a formal course for a community college 


\section{J. Social Sci., 8 (3): 472-478, 2012}

certificate. Based on this certificate, they may further their education at the diploma level. The minimum duration of the certificate course is 2 years ( 4 semesters) and the maximum period is 5 years (10 semesters). Each student is required to pass a 6-month industrial training in the third semester. For formal courses, applicants should have passed the Malaysian Certificate of Examination, although short courses are open to all. Based on the results of a tracer study by MoHE (2011), $36.4 \%$ of the 2010 community college graduates are unemployed. It is unclear whether this is because these graduates lack employability skills. Thus, the study was conducted to determine the employability skills of community college graduates.

Objectives of the study: The research was conducted with the purpose of achieving the following objectives:

- To determine the level of employability skills among community college students

- To identify community college students' employability skills as a function of

- Gender

- work experiences

- Field of study and

- Academic achievement

\section{MATERIALS AND METHODS}

This research was conducted using a survey research method. The target and accessible populations were students enrolled in public community colleges under the purview of the Malaysia Ministry of Higher Education. The students were in the fourth semester of the 2009/2010 session and enrolled in various courses. Among the courses that are chosen by students are: creative multimedia animation, integrated manufacturing technology, automotives, architectural plan drafting, building maintenance, electrical technology installation and servicing, computer system and support, hotel and catering, fashion and apparel design, food processing and quality control, construction technology, information technology, business accounting, creative multimedia advertising, air conditioning and refrigeration, travel and tourism, interior design, landscape and nursery management, beauty and hair dressing, bakery and confectionary, industrial ceramics and furnituremanufacturing technology.

Subjects for the study were identified based on the 2010 list of students provided by the Sector of Polytechnic and Community Colleges, Malaysia Ministry of Higher Education. As of 2010, the student population was 5,380. A sample of 448 students (based on s formula,) (Cochran, 1977) was randomly selected for the study. Data were collected using a questionnaire administered by the researcher. Of the 448 questionnaires distributed to the selected students, 329 were returned and 325 questionnaires were used for the analysis. Four questionnaires were discarded because they were incomplete.

Research instrument: We used a questionnaire developed by SCANS (1991) that comprised 40 items assessing students' employability skills. The participants responded to each of the statements using five-point Likert scales. A pilot study was conducted using 30 final semester students at a community college. The Cronbach's alpha reliability estimate of the instrument to measure employability skills was 0.85 . This was lower than the reliability estimate of 0.95 obtained by Kazilan et al. (2009) and 0.96 by Bakar and Hanafi (2007).

\section{RESULTS}

Characteristics of Community College Students: The respondents in this study as shown in Table 1, were between 17 and 26 years old, with a mean age of 20.32 years and a standard deviation of 1.11 years. The majority $(256 ; 78.8 \%)$ of the respondents were younger than 20 years. 174 respondents $(53.5 \%)$ were male students and $151(46.5 \%)$ were female students. A large number of respondents had technical and vocational education backgrounds $(138,42.5 \%)$ at secondary school. 93 students $(28.6 \%)$ were in humanities-related programs and $41(12.6 \%)$ came to the community college with pure science backgrounds. Approximately $16 \%$ of the respondents did not indicate their academic background at secondary school.

The analysis shows that most respondents (206, $63.4 \%$ ) had work experience before enrolling at community college. Only 119 students $(36.6 \%)$ had no work experience before their enrollment. Students' academic performance at community college was measured using a Cumulative Grade Point Average (CGPA). We divided the students' academic performances into 3 categories: 3.50 to $4.00,3.00$ to 3.49 and 2.00 to 2.99 . The majority of the respondents $(67.1 \%)$ earned a CGPA from 3.00 to $3.49,21.5 \%$ of the students obtained a CGPA between 2.00 to 2.99 and $1.4 \%$ of the respondents obtained a CGPA between 3.50 and 4.00. 


\section{J. Social Sci., 8 (3): 472-478, 2012}

Table 1: Demographic information of the respondents

\begin{tabular}{lrr}
\hline Demographic factors & Frequency & $(\%)$ \\
\hline Age & & \\
Below 20 & 256 & 78.8 \\
$21-23$ & 59 & 18.2 \\
$24-26$ & 10 & 3.1 \\
Gender & 174 & 53.5 \\
Male & 151 & 46.5 \\
Female & & \\
Field of study at secondary school & 93 & 28.6 \\
Humanities & 41 & 12.6 \\
Pure science & 138 & 42.4 \\
Technical and vocational & 53 & 16.3 \\
Not sure & & \\
Work experience & 206 & 63.4 \\
Yes & 119 & 36.6 \\
No & & \\
Academic Achievement (CGPA) & 37 & 11.4 \\
$3.50-4.00$ & 218 & 67.1 \\
$3.00-3.49$ & 70 & 21.5 \\
$2.00-2.99$ & & \\
\hline Note: $\mathrm{n}=325$ & &
\end{tabular}

The overall mean of employability skills among community college students was 3.63 (S. D. $=0.47$ ). With this mean, we would consider the employability skills of these community college students to be moderately high. The mean score was slightly lower than the scores obtained by Kazilan et al. (2009) whose study indicated that the mean score of technical trainees who attended technical training institutes was 3.86, with an S. D. of 0.36 and by Bakar and Hanafi (2007) where their findings showed that mean scores was 3.80 with an S. D. of 0.55 .

Of all measures of employability skills, the students scored the highest on personal qualities (Mean $=3.86$, S.D. $=0.59$ ). The lowest score was in resource skills $(\mathrm{M}=3.52 \mathrm{:}$ S. $\mathrm{D} .=0.55)$. Three aspects of employability were above the mean: basic skills $(\mathrm{M}=$ 3.66, S. D. $=0.59)$, interpersonal skills $(\mathrm{M}=3.72$, SD. $=0.71)$ and personal qualities $(\mathrm{M}=3.86, \mathrm{SD} .=0.59)$. The three aspects of employability that were below the mean were thinking skills $(\mathrm{M}=3.61, \mathrm{SD} .=0.62)$, resource skills $(\mathrm{M}=3.52, \mathrm{SD} .=0.55)$ and informational skills $(\mathrm{M}=3.55, \mathrm{SD} .=0.59)$. A detailed analysis of the employability measures can be seen in Table 2.

We tested the hypothesis that the employability skills of male and female community college students do not differ significantly. An independent sample t-test was conducted to compare the employability skills of male and female community college students. The result showed that there was no significant difference in the general employability skills of male $(\mathrm{M}=3.65$; S.D. $=$ $0.49)$ and female students $(\mathrm{M}=3.62$; S.D. $=0.46) ; \mathrm{t}$ $(323)=0.63, \mathrm{p}=0.53$ Table 3 .
Table 2. Means and standard deviations of employability skills

\begin{tabular}{|c|c|c|}
\hline Employability Skills & Mean & S.D. \\
\hline \multicolumn{3}{|l|}{ Basic skills } \\
\hline Reading & 3.66 & 0.78 \\
\hline Writing & 3.61 & 0.82 \\
\hline Mathematics & 3.33 & 0.84 \\
\hline Listening & 3.89 & 0.85 \\
\hline Communication & 3.81 & 0.85 \\
\hline Total & 3.66 & 0.59 \\
\hline \multicolumn{3}{|l|}{ Thinking skills } \\
\hline Creative and innovative thinking & 3.67 & 1.75 \\
\hline Decision making & 3.69 & 0.75 \\
\hline Problem solving & 3.58 & 0.76 \\
\hline Critical thinking & 3.67 & 0.83 \\
\hline Understanding learning & 3.51 & 0.77 \\
\hline Reasoning & 3.52 & 0.81 \\
\hline Total & 3.61 & 0.62 \\
\hline \multicolumn{3}{|l|}{ Resource } \\
\hline Time management & 3.62 & 0.76 \\
\hline Financial management & 3.56 & 0.80 \\
\hline Resource and facility management & 3.51 & 0.71 \\
\hline Human resource management & 3.44 & 0.73 \\
\hline Risk management & 3.47 & 0.81 \\
\hline Total & 3.52 & 0.55 \\
\hline \multicolumn{3}{|l|}{ Informational } \\
\hline Obtaining and evaluating information & 3.51 & 0.74 \\
\hline Arranging and preserving information & 3.57 & 0.76 \\
\hline Translating and disseminating information & 3.44 & 0.75 \\
\hline Using the computer to process information & 3.69 & 0.85 \\
\hline Total & 3.55 & 0.59 \\
\hline \multicolumn{3}{|l|}{ Interpersonal skills } \\
\hline Participation & 3.72 & 0.84 \\
\hline Teaching friends & 3.76 & 0.80 \\
\hline Entertaining customers & 3.74 & 0.83 \\
\hline Leadership abilities & 3.81 & 2.31 \\
\hline Negotiating & 3.57 & 0.82 \\
\hline Working with different cultures & 3.71 & 0.80 \\
\hline Total & 3.72 & 0.71 \\
\hline \multicolumn{3}{|l|}{ System and technology skills } \\
\hline Understanding system & 3.55 & 0.75 \\
\hline Monitoring and improving implementation & 3.48 & 0.74 \\
\hline Choosing technology & 3.57 & 0.80 \\
\hline Applying technology to job & 3.60 & 0.81 \\
\hline Improving apparatus damage & 3.46 & 0.86 \\
\hline Total & 3.53 & 0.62 \\
\hline \multicolumn{3}{|l|}{ Personal qualities } \\
\hline Responsibility & 3.90 & 0.83 \\
\hline Trust & 4.09 & 0.84 \\
\hline Social abilities & 3.84 & 0.79 \\
\hline Organizing & 3.73 & 0.74 \\
\hline Integrity and honesty & 3.95 & 0.82 \\
\hline Prudence & 3.84 & 0.76 \\
\hline Flexible adaptation abilities & 3.70 & 0.79 \\
\hline Ability to work without supervision & 3.71 & 0.76 \\
\hline Work safety & 3.98 & 0.81 \\
\hline Total & 3.86 & 0.59 \\
\hline Overall employability skills & 3.63 & 0.47 \\
\hline
\end{tabular}

Note: $\mathrm{n}=325$

However, significant differences were found for two constructs of employability skills: thinking skills and system and technology skills $(\mathrm{t}=2.5 ; \mathrm{p}=0.010$ and $\mathrm{t}=$ 1.98; $p=0.048)$. The magnitude of the difference in the means was very small (eta squared $=0.001$ ), which in Cohen (1988) terms, would be considered a small effect size. 
J. Social Sci., 8 (3): 472-478, 2012

Table 3: Means and standard deviations of employability skills based on gender

\begin{tabular}{|c|c|c|c|c|c|c|c|}
\hline Aspects & Gender & $\mathrm{n}$ & Mean & S.D. & DF & $\mathrm{t}$ & $\mathrm{p}$ \\
\hline & Male & 174.00 & 3.63 & 0.61 & 323 & -0.81 & 0.420 \\
\hline \multirow[t]{2}{*}{ Basic skills } & Female & 151 & 3.69 & 0.56 & & & \\
\hline & Male & 174.00 & 3.69 & 0.63 & 323 & 2.59 & 0.010 \\
\hline \multirow[t]{2}{*}{ Thinking skills } & Female & 151 & 3.51 & 0.59 & & & \\
\hline & Male & 174.00 & 3.50 & 0.57 & 323 & -0.60 & 0.550 \\
\hline \multirow[t]{2}{*}{ Resource skills } & Female & 151 & 3.54 & 0.54 & & & \\
\hline & Male & 174.00 & 3.55 & 0.59 & 323 & -0.20 & 0.841 \\
\hline \multirow[t]{2}{*}{ Informational skills } & Female & 151 & 3.56 & 0.59 & & & \\
\hline & Male & 174.00 & 3.74 & 0.76 & 323 & 0.59 & 0.554 \\
\hline \multirow[t]{2}{*}{ Interpersonal skills } & Female & 151 & 3.69 & 0.64 & & & \\
\hline & Male & 174.00 & 3.60 & 0.64 & 323 & 1.98 & 0.048 \\
\hline \multirow[t]{2}{*}{ System and technology } & Female & 151 & 3.46 & 0.59 & & & \\
\hline & Male & 174.00 & 3.85 & 0.60 & 323 & -0.35 & 0.730 \\
\hline \multirow[t]{2}{*}{ Personal quality } & Female & 151 & 3.87 & 0.51 & & & \\
\hline & Male & 174.00 & 3.65 & 0.49 & 323 & 0.63 & 0.529 \\
\hline Overall employability skills & Female & 151 & 3.62 & 0.46 & & & \\
\hline \multirow[t]{2}{*}{ Aspects } & Work experiences & $\mathrm{n}$ & Mean & S.D. & DF & $\mathrm{t}$ & $\mathrm{p}$ \\
\hline & Yes & 206 & 3.66 & 0.60 & 323 & 0.17 & 0.863 \\
\hline \multirow[t]{2}{*}{ Basic skills } & No & 119 & 3.65 & 0.56 & & & \\
\hline & Yes & 206 & 3.62 & 0.62 & 323 & 0.61 & 0.544 \\
\hline \multirow[t]{2}{*}{ Thinking skills } & No & 119 & 3.58 & 0.61 & & & \\
\hline & Yes & 206 & 3.54 & 0.59 & 323 & 0.65 & 0.513 \\
\hline \multirow[t]{2}{*}{ Resource skills } & No & 119 & 3.50 & 0.50 & & & \\
\hline & Yes & 206 & 3.55 & 0.62 & 323 & -0.03 & 0.978 \\
\hline \multirow[t]{2}{*}{ Informational skills } & No & 119 & 3.55 & 0.54 & & & \\
\hline & Yes & 206 & 3.73 & 0.58 & 323 & 0.49 & 0.627 \\
\hline \multirow[t]{2}{*}{ Interpersonal skills } & No & 119 & 3.70 & 0.88 & & & \\
\hline & Yes & 206 & 3.55 & 0.63 & 323 & 0.78 & 0.436 \\
\hline \multirow[t]{2}{*}{ System and technology } & No & 119 & 3.50 & 0.61 & & & \\
\hline & Yes & 206 & 3.89 & 0.54 & 323 & 1.30 & 0.194 \\
\hline \multirow[t]{2}{*}{ Personal qualities } & No & 119 & 3.80 & 0.65 & & & \\
\hline & Yes & 206 & 3.65 & 0.48 & 323 & 0.73 & 0.468 \\
\hline General employability skills & No & 119 & 3.61 & 0.47 & & & \\
\hline
\end{tabular}

Table 5: Means and standard deviations of students' employability skills based on academic concentrations at the secondary school

\begin{tabular}{lrllll}
\hline CGPA & $\mathrm{n}$ & Mean & S.D. & $\mathrm{F}$ & 0.75 \\
\hline Humanities & 93 & 3.63 & 0.43 & 0.51 \\
Pure science & 41 & 3.73 & 0.53 & \\
Technical and vocational & 138 & 3.63 & 0.37 & \\
Unsure sure & 53 & 3.58 & & \\
\hline
\end{tabular}

Note: $\mathrm{F}(3,321)=0.75, \mathrm{p}>0.05$

Hypothesis 2: There is no significant difference in employability skills as a function of work experience: To identify differences in employability skills as a function of work experience, a t-test was conducted. As shown in Table 4. 206 respondents worked before enrolling in community colleges and 119 respondents did not work prior to enrollment in community colleges. The result of an independent t-test showed that there was no significant difference in employability skills between the two groups (students with work experience $(\mathrm{M}=3.65$, S.D $=0.48)$ and students without work experience $(\mathrm{M}=3.61$, S.D = $0.47 ; \mathrm{t}(323)=0.73, \mathrm{p}=0.5$, respectively). The magnitude of the differences in the means was very small (eta squared $=0.002$ ).
Hypothesis 3: Students' employability skills do not differ as a function of academic concentration while at secondary school: A One-Way Analysis Of Variance (ANOVA) was conducted to test this hypothesis. Subjects were divided into four groups according to their academic concentration while at secondary school: humanities (group 1); pure science (group 2); technical and vocational (group 3); and unsure (group 4). There was no statistically significant difference at the $p<0.05$ level of employability among the four groups of students $[\mathrm{F}(3,321)=0.75, \mathrm{p}=0.52]$.

Table 5 provides the mean scores and standard deviations for the level of employability skills among the four groups of students according to their academic concentrations. 


\section{J. Social Sci., 8 (3): 472-478, 2012}

Table 6: Means and standard deviations of students' employability skills based on academic achievement

\begin{tabular}{llllll}
\hline CGPA & $\mathrm{n}$ & Mean & S.D. & $\mathrm{F}$ & $\mathrm{p}$ \\
\hline $3.50-4.00$ & 37 & 3.68 & 0.42 & 0.22 & 0.80 \\
$3.00-3.49$ & 218 & 3.63 & 0.48 & & \\
$2.00-2.99$ & 70 & 3.63 & 0.50 & & \\
\hline Note: $\mathrm{F}(2,322)=0.22, \mathrm{p}>0.05$ & & & &
\end{tabular}

Even though the differences were not significant, interestingly, the "pure science" group had the highest mean score $(\mathrm{M}=3.73$, S.D. $=0.51)$. The "not sure" group scored the lowest $(\mathrm{M}=3.58, \mathrm{~S} . \mathrm{D}=0.37)$.

Hypothesis 4: Students' employability skills do not differ as a function of academic achievement: A One-Way Analysis Of Variance (ANOVA) was conducted to explore the difference in students' employability skills based on academic achievement. Subjects were divided into three groups according to their CGPA: Group 1 (CGPA of 3.50 to 4.00), Group 2 (CGPA of 3.00 to 3.49) and Group 3 (CGPA of 2.00 to 2.99). There was no significant difference (Table 6) in students' employability skills as a function of academic achievement $[\mathrm{F}(2,322)=0.30, \mathrm{p}=0.75]$.

\section{DISCUSSION}

In general, the employability skills of community college students were moderately high $($ Mean $=3.63 ;$ S. D. $=0.47)$. However, the mean was lower than the findings of Kazilan et al. (2009) and of Bakar and Hanafi (2007), which found that the mean employability skill scores of Malaysian vocational trainees was 3.86 and 3.8 , respectively. The results of this study show no significant difference in employability skills as a function of gender. However, specific constructs of employability skills, thinking skills $(\mathrm{t}=2.59, \mathrm{p}=0.010)$ and system and technology skills $(t=1.98, \mathrm{p}=0.048)$ differ as a function of gender, with male students obtaining significantly higher mean scores than female students $($ Mean $=3.69, \mathrm{SD}=0.63 ;$ Mean $=3.51, \mathrm{SD}=0.59$, respectively). Male students also obtained a higher mean score in system and technology skills compared to female students (Mean $=3.60$, S.D $=0.64$; Mean= 3.46 , S.D $=0.59$, respectively).

The findings in this study corroborated the findings by Mitchell (2001). However, her findings showed that the perceptions of female students towards these skills were more important than the perceptions of male students. Similarly, a study by Kazilan et al. (2009) showed that employability skills differed as a function of gender. Specifically, basic skills and information skills differed significantly as a function of gender, with female students exhibiting greater levels of these skills compared to male students. Bakar and Hanafi (2007) also found that sepcific employability skills, basic skills and personal quality differed significantly between male and female respondents.

The results of a t-test showed no significant difference between students' employability skills and students' work experiences $(\mathrm{t}(206)=0.73, \mathrm{p}>0.05)$. Students' employability skills are not a function of work experience. The results differ from those of some published studies (Marjahan and Newman, 2009; Orner, 2009; McConomy, 2010; Munro, 2007; Bennett, 2006). These studies have claimed that gaining realistic experience is crucial before entering the job market and emphasized the significant role played by work experience in improving students' employability skills and opportunities for career enhancement.

It is often suggested that work experience plays an important role in the development of employability skills. Contrary to expectations, this study did not find a significant difference in employability skills between students as a function of work experience. Based on the initial observation of the programs offered at community colleges, students attend the internship program throughout the learning process. However, the employability skills that students acquire are moderately high. This finding shows that internship does not help students acquire employability skills, although it may help students improve their technical skills. Thus, the institution must consider how to ensure that students acquire employability skills through internships, which must be implemented purposefully. A contract must be signed by each student, the employer and the supervisor to ensure that the student's work provides employability skills. An internship of two to three months may be too short for students to acquire employability skills. Work experience through internships or work placement can enhance students' skills, including communication, the use of information and communication technology, problem solving and teamwork. The application of employability skills gained through work experience is abstract and may occur inadvertently as a result of a number of factors, such as social relationships, career maturity and the enhancement of technical skills. A study by Paisey and Paisey (2010) showed that work experience gained through work placement for one year successfully develops a range of transferable personal skills for students. This finding has an important implication for the development of new curricula for community colleges that can ensure that students possess a certain level of employability skills before they enter the job market. 


\section{J. Social Sci., 8 (3): 472-478, 2012}

A One-Way Analysis Of Variance (ANOVA) was used to explore the difference in students' employability skills based on their previous fields of study. However, the observed difference between employability skills and field of study was not significant at the $\mathrm{p}<0.05$ level for the four groups: $\mathrm{F}(3$, $321)=0.75, p=0.52$. The one-way ANOVA results showed that there was no significant difference in the mean employability scores between students based on academic achievement.

\section{CONCLUSION}

Based on the the present study, it is found that the employability skills of the graduates are at a moderate level and may hinder their opportunities to employed. Therefore, it is suggested that institutions must make a greater effort to help students acquire the employability skills required by many organizations. The development of employability skills should be integrated into the curriculum to ensure that students graduate from these institutions with the skills needed by employers. If institutions do not attempt to integrate the development of these skills, programs such as the One Malaysia Training Scheme, better known as SL1M, will need to be continued, which is costly for the government. Thus, institutions must find ways to ensure that their graduates are well equipped with the needed skills. It is true that Malaysia needs high-skilled workers to propel the country toward a high-income society, but these high-skilled workers need employability skills. Jobs change rapidly and workers must be able to adapt to these changes if they are to contribute to the economic development of the country.

\section{REFERENCES}

Bakar, A.R. and I. Hanafi, 2007. Assessing employability skills of technical-vocational students in Malaysia. J. Soc. Sci., 3: 202-207. DOI: $10.3844 /$ jssp.2007.202.207

Bennett, T.M., 2006. Defining the importance of employability skills in career/technical education. Dissertation ProQuest Information and Learning Company.

Burgaz, B., 2008. Employability competences of vocational secondary school students. Eurasian J. Educ. Res., 31: 17-34.

CBC, 2000. Employability Skills Toolkit for the Selfmanaging Learner. 1st Edn., Conference Board of Canada, Ottawa, ISBN-10: 0070878471, pp: 10.

Cochran, W.G., 1977. Sampling Techniques. 3rd Edn., Wiley, New York, ISBN-10: 047116240X, pp: 428.
Cohen, J., 1988. Statistical Power Analysis for the Behavioral Sciences. 2nd Edn., Routledge, Hillsdale, NJ., ISBN-10: 0805802835, pp: 567.

GM, 2010. The Tenth Malaysia Plan.

ILO, 2010. Global Employment Trends for Youth. 1st Edn., International Labour Office, Geneva, ISBN10: 9221238555 , pp: 80.

Kazilan, F., Hamzah, R. and Bakar, A.R., 2009. Employability Skills Among the Students of Technical and Vocational Training Centers in Malaysia. Eur. J. Soc. Sci., 9: 147-160. Knight, P. and M. Yorke, 2003. Learning, Curriculum and Employability in Higher Education. 1st Edn., Routledge, London, ISBN-10: 0415303427, pp: 256.

Kwok, M., 2004. Towards an understanding of employability skills development among university graduates for workplace entry. The University of Manitoba.

Marjahan, B. and R. Newman, 2009. Evaluation of students' experiences of developing transferable skills and business skills using a business simulation game. Proceedings of the 39th IEEE International Conference on Frontiers in Education Conference (FIE '09), ACM Press, NJ, USA., pp: 92-97.

McConomy, S., 2010. Work experience and internship 2010. University of Ulster.

Mitchell, T.D., 2001. An investigation of the pattern scaling technique for describing future climates. Ph.D. Thesis, University of East Anglia, United Kingdom.

Munro, J., 2007. Fostering internationally referenced vocational knowledge: A challenge for international curricula. J. Res. Int. Educ., 6: 67-93. DOI: $10.1177 / 1475240907074790$

NEAC, 2010. New economic model for Malaysia.

Orner, M.M., 2009. Employability Skill Acquisition of Career and Technical Education Students. 1st Edn., Duquesne University, ISBN: 1109201214. pp: 150 .

Paisey, C. and N.J. Paisey, 2010. Developing skills via work placements in accounting: Student and employer views. Account. Forum, 34: 89-108. DOI: 10.1016/j.accfor.2009.06.001

Robinson, J., 2000. Alabama's ability to meet workforce demands of the new economy. The Workplace.

SCANS, 1991. What work requires of school: A SCANS report for AMERICA 2000. Report of the secretary's commission on achieving necessary skills. US Department of Labor. 